\title{
Evaluation of lemon fruit extract as an antioxidant agent against histopathological changes induced by cyclophosphamide in the testes of albino mice
}

Salwa Mohammed Quita

Department of Biology, Faculty of Science, King Abdulaziz University, Jeddah, Saudi Arabia

\section{Type of article: Original}

\begin{abstract}
Introduction: The aim of this study was to determine the protective effects of lemon fruit extracts (LFE) against histopathological changes induced in the testes of male mice treated with cyclophosphamide (CP).

Methods: Thirty male mice were divided evenly into six groups: 1) group 1: the controls, 2) group 2: treated with LFE (10 ml/kg b wt.), 3) group 3: treated with CP (10 mg/kg b wt.), 4) group 4: treated with CP (20 mg/kg b wt.), 5) group 5: treated with LFE $(10 \mathrm{ml} / \mathrm{kg})+\mathrm{CP}(10 \mathrm{mg} / \mathrm{kg})$, 6) group 6: treated with $\mathrm{LFE}(10 \mathrm{ml} / \mathrm{kg})+\mathrm{CP}(20$ $\mathrm{mg} / \mathrm{kg}$ ).

Results: Histological examination of the testes of mice treated with CP revealed histopathological changes, such as atrophy, degeneration, incomplete spermatogenic series in most seminiferous tubules, and spermatogenic necrosis with pyknotic nuclei. Advanced degree of improvement was seen in testes of mice treated with LFE coadministered with CP. Most of the seminiferous tubules restored their normal structure and spermatogenic layers appeared semi-normal with complete spermatogenic series.

Conclusion: Lemon fruit extract in conjunction with drug treatment protects the testicular tissue against CPinduced testicular injury in mice.
\end{abstract}

Keywords: cyclophosphamide, lemon fruit, histopathological changes, testes, mice

\section{Introduction}

Cyclophosphamide (CP) is known a cytotoxic agent, and it is used in the treatment of various neoplastic diseases and as an immunosuppressant in organ transplantation (1). Cyclophosphamide is required for the metabolic activation by the hepatic microsomal cytochrome P450 mixed function oxidise system, and this is considered the main mechanism of both the therapeutic and the toxic effects. Phosphoramide mustard and acrolein are the two active metabolites of CP (2). Kern and Kehrer (3) reported that phosphoramide mustard has antineoplastic effects, while acrolein may be responsible for toxic side effects, such as cell death, apoptosis, oncosis, and necrosis. Moreover, cyclophosphamide produces a wide range of adverse effects, including testicular toxicity in humans and in experimental animals $(4,5)$. Several workers have indicated that cyclophosphamide alters human fertility. Its toxicity is focused on the rapidly-dividing cells, which makes highly proliferative testes targets for the damaging effects of this drug (6). Spermatogenic cells are the most affected cells by CP alkylation by DNA cross-links and DNA double-strand breaks (7). Adult male patients treated with cyclophosphamide have demonstrated increase of incidence of oligo-and azoospermia in their testicular tissue $(6,8)$. Several workers indicated that the toxic effect of $\mathrm{CP}$ on male rats/mice was found to be decreased testicular weight, oligospermia, decreased DNA synthesis in spermatogonia and protein synthesis in the spermatids, as well as biochemical and histological changes in the testis and epididymis (9-11). Disruption of the redox balance of tissue leading to oxidative stress by CP was also reported $(4,12)$. Chronic administration of CP to male rats caused testicular toxicity as assessed by glucose-6-phosphate dehydrogenase, abnormal levels of enzymes (superoxide dismutase (SOD), catalase (CAT), glutathion peroxidase (GPx), glutathion-s-transferase (GST) and glutathion reductase (GR), and antioxidants (reduced glutathion, ascrobate and $\alpha$-tocopherol) (13). Treatment of male mice with CP showed enhancement of lipid peroxidation

\section{Corresponding author:}

Salwa Mohammed Quita, Department of Biology, Faculty of Science, King Abdulaziz University, Jeddah, Saudi Arabia, E-mail: doctorsalwa@gmail.com

Received: November 14, 2015, Accepted: December 15, 2015, Published: January 2016

iThenticate screening: December 16, 2015, English editing: January 02, 2016, Quality control: January 07, 2016

(C) 2015 The Authors. This is an open access article under the terms of the Creative Commons Attribution-NonCommercialNoDerivs License, which permits use and distribution in any medium, provided the original work is properly cited, the use is non-commercial and no modifications or adaptations are made. 
leading to testicular reproductive toxicity and decreased antioxidant activity, especially SOD3 and Gpx1 (14). Furthermore, oxidative stress plays a critical role in the pathogenesis of male reproductive toxicity induced by $\mathrm{CP}$ $(15,16)$. CP produces a high level of active free radicals and reactive oxygen species (ROS) peroxide (15), and thus may be lead to spermatogenesis dysfunction or even to sperm's death. Clinical evidence proved that oxidative stress is associated with the administration of CP. The presence of rich polyunsaturated fatty acids in the mitochondrial membrane of sperm and low amounts of antioxidants makes sperm more susceptible to lipid peroxidation (8, 17). Biological compounds with antioxidant properties intake can ameliorate the toxic effects of chemotherapy and may protect cells and tissue from deleterious effects of reactive oxygen species and other free radicals induced by $\mathrm{CP}$ (18). The extract of lemon fruit is rich in proanthocyaidins, flavonoids, hesperidin, eriocitrin, and vitamins $\mathrm{E}$ and $\mathrm{C}$ (19). Many of these phenolic compounds have been shown to be cytoprotective by scavenging superoxide anions, hydroxyl radicals, and hydrogen peroxide, thereby reducing lipid peroxidation $(20,21)$. Therefore, the present study aimed to investigate the possible protective effects of lemon fruit extract against CP-induced testicular injury in mice.

\section{Material and Methods}

\subsection{Materials}

The following materials were used in this study: 1) Cyclophosphamide: known commercially as Endoxan, it was purchased from Baxter Oncology, Halle, Germany, and dissolved in saline solution; 2) Lemon fruit extracts: The lemon fruits were obtained from Jeddah market, Saudi Arabia. They were washed with distilled water, cut into many small pieces, ground in a mixer (Moulinex type 753) and then were eaten by the tested animals.

\subsection{Animals}

Swiss albino male mice (Mus musculus $2 \mathrm{n}=40$ ) MFI strain, 8-9 weeks old, weighting $30 \pm 3 \mathrm{~g}$ were obtained from the animal house at the King Fahad Medical Center at King Abdulaziz University in Jeddah. The animals were housed in polyplastic cages with steel wire tops in an air conditioned room $\left(22 \pm 1{ }^{\circ} \mathrm{C}, 45-75 \%\right.$ relative humidity) with $12 \mathrm{~h}$ light $/ 12 \mathrm{~h}$ dark cycles. Food and water were provided ad libitum.

\subsection{Methods}

Thirty male mice were divided into six groups (each containing five mice) as follows: Group one (Gr1) was treated with saline solution on intraperitoneal (i.p.) as a vehicle control, group two (Gr2) was treated with LFE by oral intubation (o.i.) (10ml / kg b wt.), group three (Gr3) was treated with CP (10mg / kg b wt.) (i.p.), group four (Gr4) was treated with CP (20mg / kg b wt.) (i.p.), group five (Gr5) was treated with LFE $10 \mathrm{ml} / \mathrm{kg}(\mathrm{o} . \mathrm{i}$.) $+\mathrm{CP} 10 \mathrm{mg} / \mathrm{kg}$ (i.p.), group six (Gr6) was treated with LFE $10 \mathrm{ml} / \mathrm{kg}$ (o.i.) + CP 20mg / kg (i.p.).

\subsection{Animal treatment}

CP was introduced by intraperitoneal (i.p.) injection as recommended by Anton (22). LFE was given by oral intubation (o.i.) as reported by Sakr et al. (23). All groups were treated daily for five consecutive days (24). The mice were killed $24 \mathrm{~h}$ after the last dose.

\subsection{Tissue procurement}

Upon the injection, the mice were killed and dissected, the testes were removed and dried, and part of the testes was used for histological examination.

\subsection{Histology}

The tissues were fixed overnight in $10 \%$ buffered neutral formalin processed to paraffin wax, sectioned at5 mM, and stained with haematoxylin and eosin $(\mathrm{H}+\mathrm{E})$ (25) for examination by light microscopy (Olympus BX51).

\section{Results}

The testes of the control group had built up a large number of seminiferous tubules, which were held together by an intertubular connective tissue that contained particular interstitial cells (Leydig cells). Seminiferous tubules appeared as rounded or oval structures, each surrounded by a thin basement membrane that had in its wall several layers of cells representing (from outside inwards): 1) Spermatogonia, which lie along the periphery of the tubules from inside, i.e., packed cells; 2) Primary spermatocytes, which are the largest of the cells and have large nuclei; 3) Secondary spermatocytes, which are smaller than the previous cells, and their nuclei were deeply stained; 4) Spermatids, which were smaller than the previous cells, and their nuclei were more condensed; and 5) Spermatozoa, which lie in the cavity of the tubule and always were connected with the Sertoli cells (Figure 1). Testes treated with 
lemon fruit extract showed no histological alterations (Figure 2). The testes showed normal architecture with complete spermatogenic series. The testes of mice treated with CP (10 mg/kg b wt.) exhibited histological changes when compared with the controls (Figure 3). These changes showed an increase in the interconnective tissue of the seminiferous tubules, leading to its atrophy, collapse, or sloughing in epithelial germ cells of some of these tubules, and depletion in different spermatogenic, especially the primary spermatocyte, and spermatids resulting in the small thickness of stratification of most seminiferous tubules, and the emergence of vacuolization between spermatocytes, as well as that Sertoli cell nuclei were also very much affected, scarcity of sperm in the lumens of lot of the seminiferous tubules, and the small number of Leydig cells, while taking irregular forms, as well as its nuclei began to lose their natural shape, taking different forms (Figure 3).

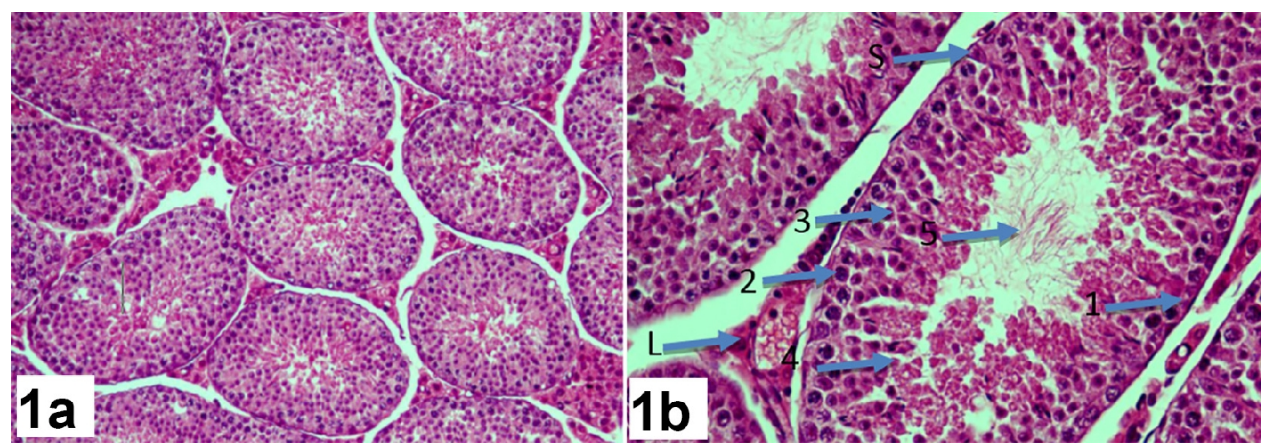

Figure 1. Transverse section in the testis of a mouse of control group showing normal structure H\&E x200 (1a), H\&E x400 (1b).1: Spermatogonia, 2: Primary spermatocytes, 3: Secondary spermatocytes, 4: Spermatids, 5: Spermatozoa - S: Sertoli cell - L: Leydig cells

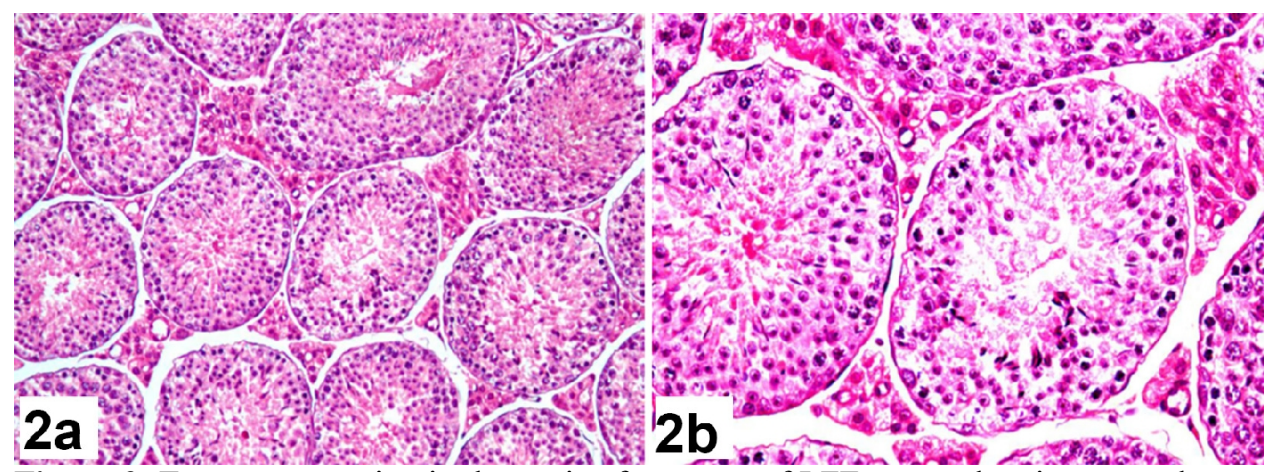

Figure 2. Transverse section in the testis of a mouse of LFE group showing normal structure H\&E x200 (2a), H\&E $\mathrm{x} 400(2 \mathrm{~b})$

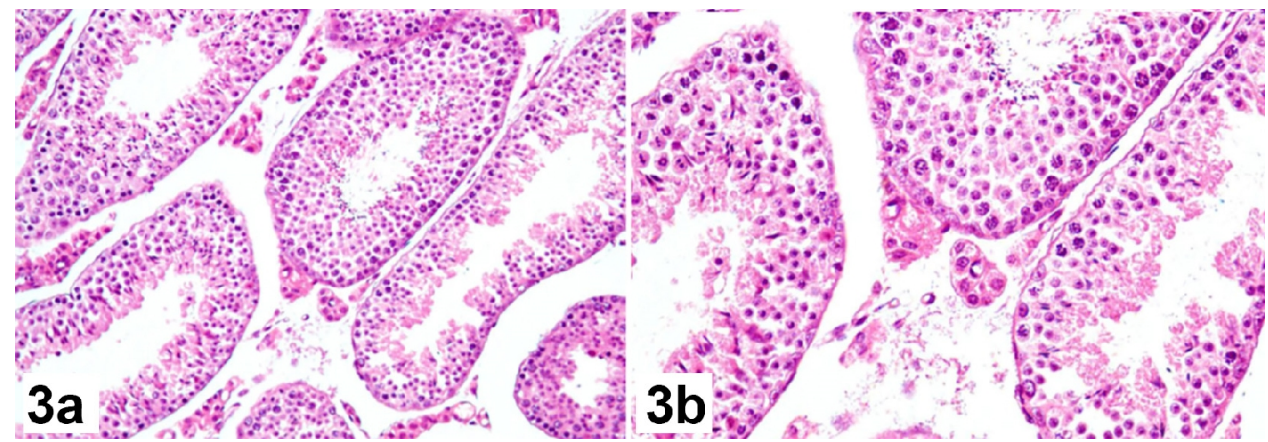

Figure 3. Transverse section in the testis of a mouse of CP group (10mg/kg) showing abnormal structure H\&E x200 (3a), H\&E x400 (3b)

On examining the treated cross-sections with the dosage of $20 \mathrm{mg} / \mathrm{kg}$ of the drug, the effect was highly apparent, where the amount of spaces between the seminiferous tubules increased with increasing in swelling in the 
intertubular connective tissue, leading to the atrophy or collapse of seminiferous tubules, beside scattered Leydig cells and a severe decrease in its number, but for the seminiferous tubules itself the basement membrane has been sloughed off the epithelial cells and a cellular retention has appeared in some seminiferous tubules, in addition to the occurrence of a complete disintegration of the nuclei of Sertoli cells and the scarcity of the sperm, spermatogenic necrosis with pyknotic, karyolysis nuclei was also detected (Figure 4). The histological examination of the testicular tissue of male mice dually treated with an extract of lemon fruit with cyclophosphamide, whether with the therapeutic dose or its double (Figure 5,6), respectively, has demonstrated a marked improvement in both treatments, as it was seen, on examining the cross-sections how much was the testicular tissue response to this treatment, as the seminiferous tubules have restored their interconnectedness with each other within the testis crosssections, and the epithelial germ cells have appeared normal. In addition, the testicular content of sperm increased, and the number of spermatocytes improved. In addition, the natural stratification order returned inside the seminiferous tubule. Also, the nuclei of the Sertoli cells were restored to their natural shape, and it was observed that the number of Leydig cells increased in number and size for all of the doses. Their nuclei also returned to their normal shape and location.
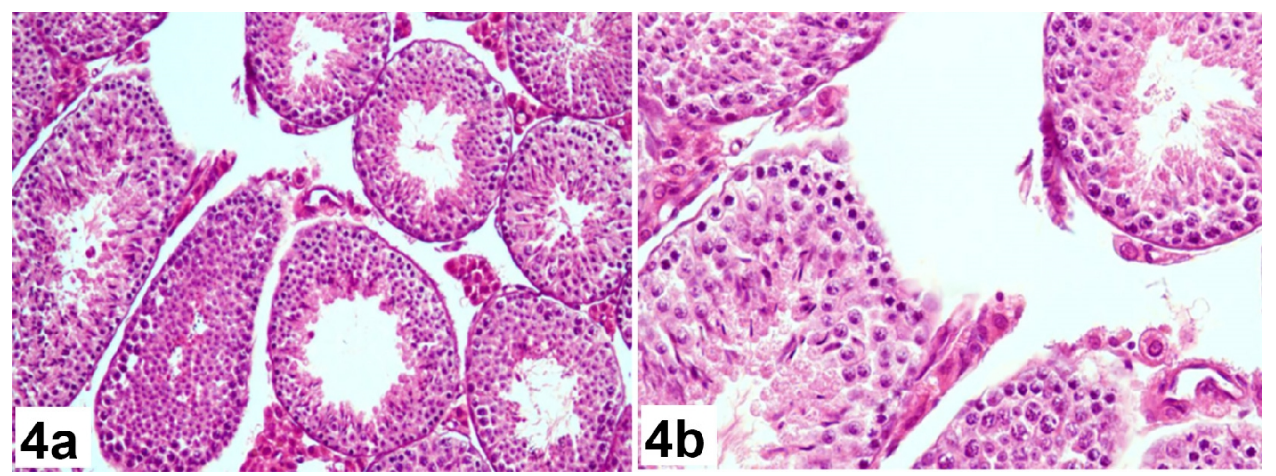

Figure 4a. Transverse section in the testis of a mouse of CP group $(20 \mathrm{mg} / \mathrm{kg})$ showing abnormal structure H\&E x200 (4a), H\&E x400 (4b)

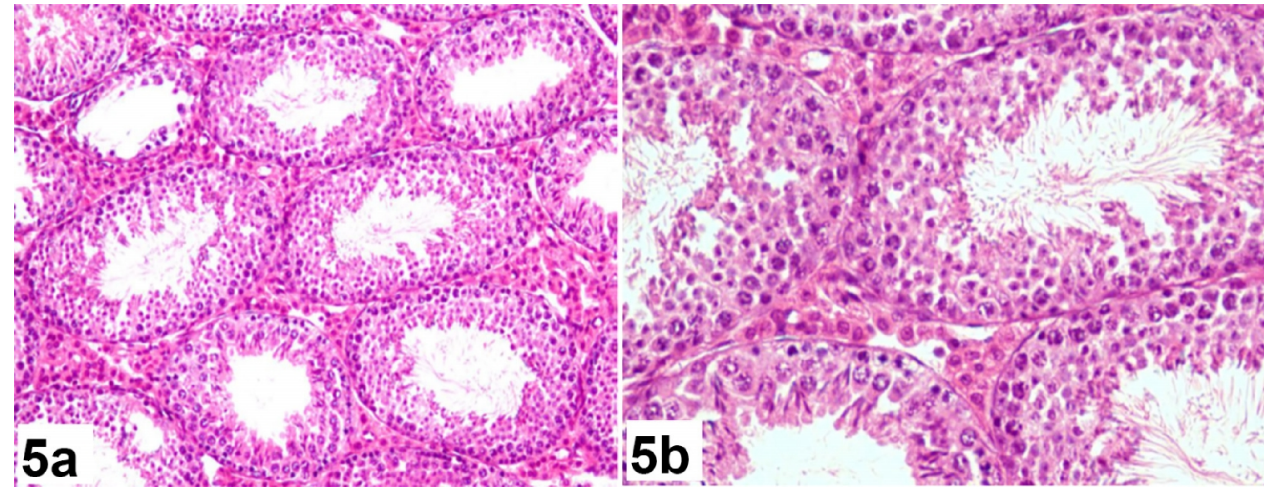

Figure 5. Transverse section in the testis of a mouse of LFE $(10 \mathrm{ml} / \mathrm{kg})+\mathrm{CP}(10 \mathrm{mg} / \mathrm{kg})$ group showing normal structure H\&E x200 (5a), H\&E x400 (5b)

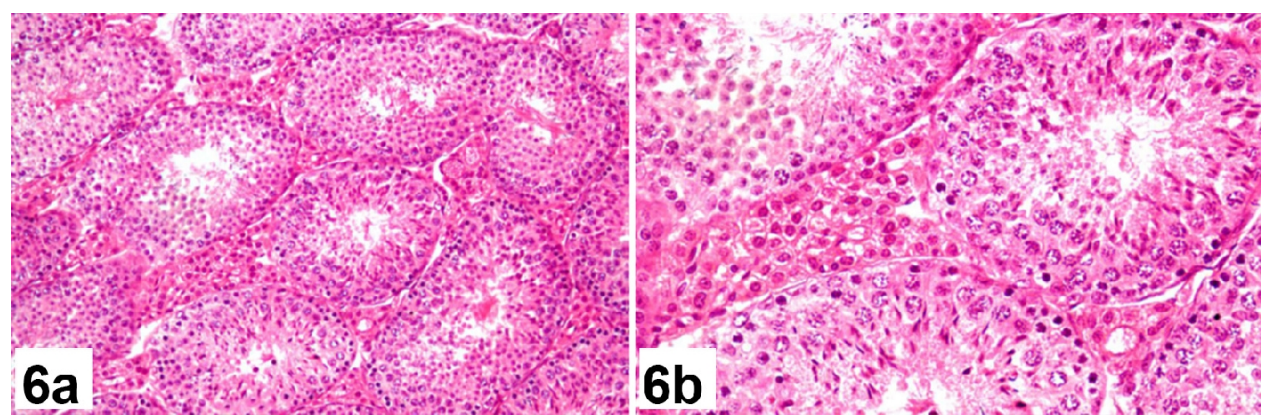

Figure 6. Transverse section in the testis of a mouse of LFE $(10 \mathrm{ml} / \mathrm{kg})+\mathrm{CP}(20 \mathrm{mg} / \mathrm{kg})$ group showing normal structure H\&E x200 (6a), H\&E x400 (6b) 


\section{Discussion}

The histological examination of the testicular tissue of male mice dually treated with cyclophosphamide, in the therapeutic and the double therapeutic doses have shown that such treatment has brought about acute histopathological changes, was presented in the emergence of irregular seminiferous tubules, as it lost its ring shape and became either atrophic or collapsed and spaced from each other and there are incomplete spermatogenic series, as well as the spermatocytes layer thickness in some tubules lessened, as its cells become degenerated, which led to the emergence of areas of vacuolization, and in some tubules there was a cellular retention flaking of the spermatocytes with sloughed basement membranes of these tubules. Odema replaced the interstitial Leydig cells, and the interstitial space widened in the intertubular connective tissue. These histological alterations were more obvious in mice treated with high doses of CP. These results were consistent with other previous studies that reported that treatment with the therapeutic dose of CP for a week or more caused injury to the testes. Gamal El-Din et al. (26) stated that daily treatment of mice and rats with CP for a week caused an apparent shortage in each of the primary spermatocytes and spermatids. Moreover, administration of CP once a week for five weeks caused oligoazoospermia and testicular damage in mice (11). Selvakumar et al. also noted that the treatment of male rats with a dose of $15 \mathrm{mg} / \mathrm{kg}$ once a week for 10 weeks resulted in damage to the seminiferous tubules and disruption in the process of spermatogenesis. They also observed that some tubules had remnants of decomposed Sertoli cells in their cavities (16). Tripathi and Jena noted that treatment of mice with CP once per week for five weeks caused germ cell toxicity (27). Jalali et al. concluded that the treatment of rats with $\mathrm{CP}$ at a dose of $5 \mathrm{mg} / \mathrm{kg} / \mathrm{day}$ for 28 days caused atrophy of the seminiferous tubules, a severe shortage of sperm cells, and the formation of intraepithelial vacuolization with the emergence of rupture and congestion of blood vessels. Also, germ cells appeared in irregular shapes and their nuclei were pyknotic, and there was infiltration in the inflammatory cells and degradation of the Leydig cells (28). Many recent studies also have indicated that the treatment of mice and rats with a severe, single dose of CP i.e., $200 \mathrm{mg} / \mathrm{kg}$, can cause atrophy, degeneration, and loss of spermatogenesis in most of the seminiferous tubules with the formation of odema that replaced the decaying interstitial Leydig cells (29-31). Also, El-Seedy et al. indicated that the treatment of mice with CP caused a significant increase in abnormal sperm, which proved that the drug has the ability to interfere in different processes of spermatogenic cells, since they also noted the presence of vacuolization and the loss of the sperm cristae in these treated mice. He attributed the emergence of these abnormal pathological conditions to DNA damage or at a specific level of differentiation of spermatozoa during development (32). It is believed that acrolein and phosphormide that produced of cyclophosphamide drug metabolism within the body are the two factors most common, and responsible for reproductive toxicity, due to their ability to the alkylation of the DNA molecule, by formation of cross-links either at strand level of DNA (DNADNA) or DNA with protein or through the creation of fragmentation at the level of a single-strand (27). Perhaps the most important thing is that the increase in the rate of process of lipid peroxidation is one of the toxic manifestations of the testes resulting from treatment with cyclophosphamide, as well as the production of acrolein also is a major source for the production of reactive oxygen species ROS (15). Selvakumar et al. pointed out that, in natural tissues and organs, there must be a state of equilibrium between the production of active oxygen species ROS and antioxidants, which serve as scavengers for such free radicals, because it is from the physiological aspect, it is required the presence of such reactive oxygen species in small and reasonable quantities, because it is necessary for fertilization and acrosome reaction (16). Vernet et al. also reported that the increased production of reactive oxygen species within tissue may lead either to break of antioxidant defense mechanisms or may exceed the capacity of the antioxidant defense system (33). In addition, the plasma membrane of the sperm is usually rich in numerous polyunsaturated fatty acids, and also the cytoplasm of the sperm contains a little of the scavenging enzymes, making the sperm more vulnerable to the attacks by and excessive ROS. Many previous studies indicated that cyclophosphamide acts on bringing about an oxidative stress and decreased levels of glutathione GSH, SOD in the testes tissue of the treated mice (14) or may lead to a severe reduction in the activities of both of the SOD, CAT enzymes resulting in an increase in lipid peroxidation (34). In addition, Kehrer and Biswal confirmed that treatment with cyclophosphamide leads to a depletion of glutathione peroxidase enzyme (GPX), through the reaction of the metabolic product of acrolein with this enzyme and that acrolein also interacts with cysteine, which is considered one of the most important essential amino acids for the enzyme glutathione peroxidase (35). Motawi et al. reported that changes taking place in lipid peroxidation and the levels of glutathione GSH are usually accompanied by a decrease in the activities of antioxidant enzymes, such as GPx and GR enzymes, and perhaps the decrease of activity of these antioxidant enzymes is what makes the sperm more likely to be damaged by free radicals (29). In addition to that, the decrease in glutathione GSH content may also lead to a decrease in the concentration of vitamin C, and the consequences of the loss of this vitamin are dangerous, because, in addition to its job as antioxidant, it also plays an important role in the regenerating process of other antioxidants (36). Ascorbic acid is also present in the 
spermatogenic chamber and in Leydig cells, and it has been shown to play an important role in steroidogenesis (34). This was confirmed by Selvakumar et al. in their study that the treatment of male rats with cyclophosphamide drug led to decreasing rates of antioxidants, such as glutathione, vitamin $\mathrm{C}$ and vitamin $\mathrm{E}$ (13). Vitamin $\mathrm{E}$ is considered as the principle lipid-soluble chain breaking antioxidants which tends to protect unsaturated fatty evidently explains the overproduction of ROS including other free radicals (36). Perhaps the increase in the production of free radicals may be one of the potential mechanisms for cyclophosphamide in bringing about the degeneration of Leydig cells, with the outcome thereof being shortage of androgens (37). As the stages of growth and maturation of germ cells into sperm is an important function of Sertoli cells, so, the logical explanation for the failure of the spermatogenesis in males treated with cyclophosphamide is the result of a disruption in the process of correlation between hormones of androgen-dependent on Sertoli cells with germ cells, which leads to disorganization and separation (38). But for the dual treatment with a lemon fruit extract with cyclophosphamide, in the two doses, the therapeutic and its double one under study, histological examination of the testes of the treated males showed the extension of the apparent improvement, as the seminiferous tubules regained their natural shapes and interdependence with each other within the tissue of the testes, and the epithelial of the germ cells appeared normal, and the testicular content of sperm increased and the number of sperm cells and its stratification improved. Sertoli cells regained their contact ties with both germ cells and sperm cells, but for Leydig cells, an increasing number of nuclei with retrieval of its natural shape was observed. There are many previous studies that have shown the role played by some of the compounds as substances have antioxidant effects, working to protect the male reproductive system against the harmful effects of reactive oxygen species ROS, as well as other free radicals, that are produced through treatment with cyclophosphamide. Das et al. (4) found that ascorbic acid reduces the effect of cyclophosphamide, causing the toxicity of the reproductive system, and in the same way alphatocopherol- succinate (39). Some studies also indicate that dietary supplements containing lipoic acid $(5,16)$, Crataegusmonogyna extract $(28)$, Saturejamontana extract (30), and melatonin (31), that may act as antioxidants leading to reduced oxidative stress for cyclophosphamide resulting in reproductive toxicity. The results of the current study show that treatment with lemon fruit extract with cyclophosphamide, in its two doses, the therapeutic and its double one were very effective in the protection of testicular tissue. And may be the most logical explanation for this is that the lemon fruit is rich of proanthocyaidins, flavonoids, hesperidin and eriocitrin (19) and many of these phenolic compounds have the ability to protect cells by removing superoxide anion, hydroxyl radical, hydrogen peroxides and reduce lipid peroxidation (20, 21). Perhaps eriocitrin has a strong anti-oxidant effectiveness more than the other citrus flavonoids compounds (19), and also giving eriocitrin serves to protect against oxidative stress in the liver of rats and scavenge free radicals and prevent the formation of superoxide and hydroperoxide (41), also believed that lemon flavonoids, eriocitrin and hesperidin may be used to increase the concentration of antioxidant enzymes, such as catalase (CAT) and glutathione (GSH), in liver tissue (19). In addition, lemon juice was found to act as a powerful antioxidant because it contains citrates, flavonoids, vitamin E, vitamin C $(19,41)$, and lemonades (42). The researchers reported that vitamin $\mathrm{C}$ can act as an anti-clastogeneic and as an anti-mutagenic agent (43), and it works as a strong anti-oxidant agent 44), and all these biological elements mentioned previously have been proved to work as scavengers of free radicals, preventing them from destroying cells and tissues.

\section{Conclusions}

The findings of our study demonstrated that cyclophosphamide can damage testicular tissue, while giving lemon fruit extract in conjunction with the drug treatment was able to protect testicular tissue against $\mathrm{CP}$-induced testicular injury in mice.

\section{Acknowledgments:}

The author is thankful to Prof. Amal El-Naggar for her help during this study.

\section{Conflict of Interest:}

There is no conflict of interest to be declared.

\section{References}

1) Traipathi DN and Jena GB. Astaxanthin intervention ameliorates cyclophosphamide-induced oxidative stress, DNA damage and early hepatocarcinogenesis in rat:role of NrF2, P53, P38 and phase-11 enzymes. Mutat Res, 2010; 696:69-80, doi: 10.1016/j.mrgentox.2009.12.014, PMid: 20038455

2) Ludeman SM. The chemistry of the metabolites of cyclophosphamide. Curr Pharm Des, 1999; 5:627-43. PMid: 10469895 
3) Kern JC and Kehrer JP. Acrolein-induced cell death: a caspase-influenced decision between apoptosis and oncosis/necrosis. ChemBiol Interact, 2002; 139:79-95. doi: 10.1016/S0009-2797(01)00295-2

4) Das UB, Mallick M, Debnath JM and Ghosh D. Protective effect of ascorbic acid on cyclophosphamideinduced testicular gametogenic and androgenic disorders in male rats. Asian J Androl, 2002; 4:201-7. PMid: 12364977

5) Selvakumar E, Prahalathan C, Sudharsan PT and Varalakshmi P. Chemoprotective effect of lipoic acid against cyclophosphamide-induced changes in the rat sperm. Toxicology, 2006; 217:71-8. doi: 10.1016/j.tox.2005.08.020, PMid: 16207511

6) Howell S and Shalet S. Gonadal damage from chemotherapy and radiotherapy. Endocrinol Metal Clin North AM. 1998; 27:927-43. doi: 10.1016/S0889-8529(05)70048-7

7) Aguilar_Mahecha A, Hales BF and Robair B. Effect of acute and chronic cyclophosphamide treatment on meitic progression and the induction of DNA double-strand breaks in rat spermatcytes. Bio Reprod, 2005; 72:1297-304. doi: 10.1095/biolreprod.104.038620, PMid: 15673603

8) Kim W, Kim SH, Park SK and Chang MS. Astragalus membranes ameliorates reproductive toxicity induced by cyclophosphamide in male mice. Phytother Res, 2012; 26:1418-21. doi: 10.1002/ptr.4756, PMid: 22674751

9) Meistrich ML, Parchuri N, Wilson G, Kurdoglu B and Kangasniemi M. Hormonal protection from cyclophosphamide -induced inactivation of rat stem spermatogonia. J Androl, 1995; 16:334-41. PMid: 8537251

10) Kuar F and Sangha GK. Cyclophosphamide-induced structural and biochemical changes in testis and epididymitis of rats. Indian J ExpBiol, 1997; 35:771-5.

11) ElangovanN, Chiou TJ, Tzeng WF and Chu ST. Cyclophosphamide treatment causes impairment of sperm and fertilizing ability in mice. Toxicology, 2006; 222:60-70. doi: 10.1016/j.tox.2006.01.027, PMid: 16517039

12) Manda K and Bhatia AL. Prophylactic action of melatonin against cyclophosphamide-induced oxidative stress in mice. Cell biolToxicol, 2003; 19:367-72. doi: 10.1023/b:cbto.0000013342.17370.16

13) Selvakumar E, Prahalathan C, Mythili Y and Varalakshmi P. Protective effect of DL- - Lipoic acid in cyclophosphamide induced oxidative injury in rat testis. Reproductive Toxicology, 2004; 19:163-7. doi: 10.1016/j.reprotox.2004.06.015, PMid: 15501381

14) Yuan D, Wang H, He H, Jia L, He Y, Wang T et al. Protective effects of total flavonoids from epimeduim on the male mouse reproductive system against cyclophosphamide-induced oxidative injury by upregulating the expressions of SOD3 and GPx1. Pytothe Res, 2014; 28:88-97. doi: 10.1002/ptr.4956, PMid: 23494828

15) Turk G, Geribasi AO, Sakin F, Sonmez M and Atessahin A. Antiperoxidative and anti-apoptotic effects of lycopene and ellagic acid on cyclophosphamide-induced testicular lipid peroxidation and apoptosis, PeprodFertil Dev, 2010; 22:587-96. doi: 10.1071/rd09078

16) Selvakumar E, Prahalathan C, Sudharsan PT and Varalakshmi P. Protective effect of lipid acid on cyclophosphamide-induced testicular toxicity. ClinicaChimicaActa, 2006; 367:114-9. doi: 10.1016/j.cca.2005.11.034, PMid: 16451798

17) Shathish K, Reena D and Guruvayoorappan C. Chemoprotective effect of Decalepishamiltonii against cyclophosphamide-induced toxicity. J ExpTherOncol, 2012; 9:291-301. PMid: 22545422

18) Habibi E, Shokrzadeh M, Chabra A, Naghshvar F, Keshavar Z, Maleki R, et al. Portective effects of Origanum vulgare ethanol extract against cyclophosphamide- induced liver toxicity in mice. Pharmacutical Biology, 2014; 3:1-6

19) Miyake Y, Yamamoto K, Morimitsu Y, and Osawa T. Characteristics of antioxidative flavonoid glycosides in lemon fruit. Food SciTechnolInt Tokyo, 1998; 4: 48-53. doi: 10.3136/fsti9596t9798.4.48

20) Bahorun T, Trotin F, Pommery J, Vasseur J, Pinkas M. Antioxidant activities of Crataegusmonogyna extract. Planta Med, 1994; 60:323-8. doi: 10.1055/s-2006-959493, PMid: 7938266

21) Rice-Evans C. Flavonoids and isoflavones absorption metabolism and bioactivity. Free RadicBiol Med, 2004; 36:827-8. doi: 10.1016/j.freeradbiomed.2003.12.012, PMid: 15019967

22) Anton E. Ultrastructural changes of stromal cells of bone marrow and liver after cyclophosphamide treatment in mice. Tissue and Cell, 1997; 29:1-9. doi: 10.1016/S0040-8166(97)80066-3

23) Sakr S, El-said M and El-shafey S. Ameliorative effect of grapefruit juice on amiodarone-induced cytogenetic and testicular damage in albino rats. Asian Pac J Trop Biomed, 2013; 3:573-9. doi: 10.1016/S2221-1691(13)60116-1 
24) Naghshvar F, Abianeh S, Ahmadashrafi S and Hosseinimehr S. Chemoprotective effects of carnosine against genotoxicity induced by cyclophosphamide in mice bone marrow cells. Cell BiochemFunct, 2012; 30: 569-573. doi: 10.1002/cbf.2834

25) Mallory FB. Acontribution to staining methods. Journal of Experiment Medicine, 1900; 5-15.

26) Gamal El-Din EM, EL-sayed EH and Farrag KA. Histological and histochemical studies on the effects of cyclophosphamide on the testis and skin of mouse. Egyptian Journal of histology, 1993; 16:119-32.

27) Tripathi DN and Jena GB. Astaxanthin inhibits cytotoxic and genotoxic effects of cyclophosphamide in mice germ cells. Toxicology, 2008; 248:96-103. doi: 10.1016/j.tox.2008.03.015, PMid: 18485558

28) Jalali AS, Hasanzadeh S and Malekinejad H. Crataegusmonogynaaqueous extract ameliorates cyclophosphamide-induced toxicity in rat testis: stereological evidences. Acta Media Iranica, 2012; 50:1-8. PMid: 22267371

29) Motawi MT, Sadik NA and Refaat A. Cytoprotective effects of DL-alpha-lipoic acod or Squalene on cyclophosphamide-induced oxidative injury: An experimental study on rat myocarduim, testicles and urinary bladder. Food and Chemical Toxicology, 2010; 48:2326-36. doi: 10.1016/j.fct.2010.05.067, PMid: 20573578

30) Abd El Tawab AM, Shahin NN and AbdlMohsen MM. Protective effect of Satureja Montana extract on cyclophosphamide-induced testicular injury in rats. Chemico-Biological Interactions, 2014; 224:196-205. doi: 10.1016/j.cbi.2014.11.001, PMid: 25446862

31) Chabra A, Shokrzadeh M, Nagshvar F, Salehi F and Ahmdi A. Melatonin ameliorates oxidative stress and reproductive toxicity induced by cyclophosphamide in male mice. Human and Experimental Toxicology, 2014; 33:185-95. doi: 10.1177/0960327113489052, PMid: 23703819

32) El-Seedy AS, Taha TA, EL-Seedy MA and Maklouf AA. Ultrastructure sperm defects in male mice during carcinogenicity of urethane and indoxan. Arab Journal of Biotechnology, 2005; 9:27-40.

33) Vernet P, Aitken RJ and Drevet JR. Antioxidant strategies in the epididymis. Mol Cell Endocrinol, 2004; 216:31-9. doi: 10.1016/j.mce.2003.10.069, PMid: 15109742

34) Sakr SA, Mahran HA and Abo-El-Yazid SM. Effect of fenugreek seeds extract on cyclophosphamideinduced histomophometrical, iltrastructural and biochemical changes in testes of albino mice. Toxicology and Industrial Health, 2011; 28:276-88. doi: 10.1177/0748233711412427, PMid: 21949087

35) Kehrer JP and Biswal SS. The molecular effects of acrolein. Toxicological Sciences, 2000; 57:6-15. doi: 10.1093/toxsci/57.1.6, PMid: 10966506

36) Lee IM. Antioxidant vitamins in the prevention of cancer. Proc Assoc Am Physicians, 1999; 111:10-5. doi: 10.1046/j.1525-1381.1999.09230.x, PMid: 9893152

37) Latchoumycandane $C$ and Mathur PP. Effects of hyperthyroidism on the physiological status of pubertal rat tetis. Biomed Lett, 1999; 59:33-41.

38) Debnath D and Mandal TK. Study of quinalphos (an environmental oestrogenic insecticide) Formulation (Ekalux 25 E.C) - induced damage of the testicular tissues and antioxidant defence system in SpargueDawley albino rats. J ApplToxical, 2000; 20:197-204. doi: 10.1002/(SICI)10991263(200005/06)20:3<197::AID-JAT634>3.0.CO;2-7

39) Murk DD and Cheng CY. Sertoli-Sertoli and Sertoli-germ cell interactions and their significance in germ cell movement in the seminiferous epithelium during spermatogenesis. Endocr Rev, 2004; 25:747-806. doi: 10.1210/er.2003-0022, PMid: 15466940

40) Ghosh D, Das UB and Misro M. Protective role of alpha-tocopherol-succinate (provitamins E) in cyclophosphamide induced testicular gametogenic and steroidogenic disorders: a correlative approach to oxidative stress. Free Res, 2002; 36:1209-18. doi: 10.1080/1071576021000016472

41) Minato K, Miyake Y, Fukumoto S, Yamamoto K, Kato Y, Shimomura Y, et al. Lemon flavonoid, eriocitrin, suppresses exercise-induced oxidative damage in rat liver. Life Sci, 2003; 72: 1609-1616. doi: 10.1016/S0024-3205(02)02443-8

42) Yu J, Wang L, Walzem RL, Miller EG, Pike LM, Patil BS. Antioxidant activity of citrus limonoids, flavonoids and coumarins. J Agric Food Chem, 2005; 53: 2009-14. doi: 10.1021/jf0484632, PMid: 15769128

43) Anderson D, Basaran N, Blowers SD and Edward AJ. The effect of antioxidants on bleomycin treatment in in vitro and in vivo genotoxicity assays. Mutat Res, 1995; 329: 37-47. doi: 10.1016/0027-5107(95)00017-D

44) Rao MV. Mercuzy and its effects on mammalian system- a critical review. Indian J Environ Toxical, 1997; 7: 3-11. 